\title{
マレーシアにおける農村整備について
}

\author{
八島茂夫*
}

はじめに

東南アジアにおける経済優等国であったマレー シアは, 原油・ゴム・パーム油・錫などの主要輸 出産品の国際価格が低迷するなかで, 苦しい経済 運営を強いられている。更に, 国内では, 中国人 華僑に比へ，経済的に不利な立場にあるマレー人 の生活水準向上を目指し, マレー優遇政策が強力 に推進されている。本稿では,こうした背景のも とでの, マレーシア政府の農村整備に関する基本 方針を紹介する。更に、筆者が関保した稲作農村 の実態と, 筆者の農村整備に対する考え方を紹介 する。

\section{I マレーシアにおける農村整備政策1)}

1 第 5 次マレーシアプランにおける基本政策

1986年 3 月に制定された第 5 次マレーシアプラ ン（1986１990）では，基本政策を次のように定 め, 国民の献身的な協力と，自覚を呼び掛けてい る。70年代には年 $5 \%$ の順調な成長率を記録して いたマレーシア経済は，80年代に入り，世界的な 経済不況のあおりをまともに受け, 経済成長率 は, ほほ半滅状態となり, 厳しい局面を迎えてい る。今後も, 世界経済の先行きは不透明で, 当 面, 一次産品を中心に, 輸出の伸びはあまり期待 できない。そこで，增加する人口圧力に対処する ため, 教育の充実により，有能な人材を養成し,

*熱带農業研究センター
内需拡大により積極的に㕍用を開発し，現政権の スローガンである「貧困からの脱出」政策を推進 し, 国家の統一と，公正な社会の建設を達成する ことにしている。

\section{2 国内経済対策}

このような情勢のもとで, 政府は, 第 5 次マレ ーシアプラン期間中に, 新たに増加すると予想さ れている，88万人の㕍用の開発を迫られるとい う，䇥しい局面に遭遇している。その打開策とし て、これまで政府が実施してきた農地開発事業な どに，民間の参加を大幅に認め，その資金と技術 力を活用して，事業進捗のスピードアップと，国 内経済の大幅な拡大を図る。また，外国企業の進 出を促進し，輸出産業を育成し，国内経済の活性 化と急速な経済成長を図るとともに，マレーシア 人に生産技術・マーケティングの know how を修 得させるなどの手段により，質量两面にわたる雇 用の改善を達成する。更に、人的資源の不足から， この数年間, 生産性向上以上のペースで労貨が值 上がりし, 経済発展を妨げている。そこで, 学際 的教育よりも技術教育に力を入れ，技術労働者を 大量に供給し，労貨の值上がりを抑えようとして いる。計画書では，それにもかかわらず, 1985年 にも7.6\%あった失業率が, 1990年には10.1\%に 增加するという，縓しい見方をしている。

\section{3 「貝困からの脱出」}

基本政策の中では，国家統一の最大の障壁とな っている, 人種間の経済格差の解消が特に強調さ れている。マレーシアは, マレー人 $58 \%$, 中国人 


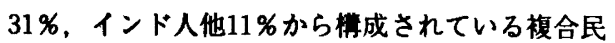
族国家である。このうち，中国人の経済分野での 活勁は極めて活発で，国の経済を完全に牛耳って いる。世帯当たり月収も，農業従事者を主体とす ろマレー人のM \$581（1984年中央值：M\$1 ¥70）に对して，商工莱従事者を主体とする中国 人はM $\$ 1,024 て ゙ ，$ 而者の間には歴然とした差が ついている (表 1 参照)。

政府は，政策上，月収 $\mathrm{M} \$ 60 /$ 人を筫困ライ ンと定めている。1984年時点においては,このラ インを下回る費困世带は，都市部では8.2\%であ ろのに対して，展村部では24.7\%に達している。 中でも，啝作辰家は57.7\%,ココナッ農家は 46.9 \%,コム貫家は $43.4 \%$ と，負困世带数の率が著し く离い。このような背柰のもとに，「負困からの 脱出」には, マレー人が73.2\%を占める展村部の 負困世带対策に，それが人種間の経済格差の解消 策にもなることもあって，重要な位置付けがなさ れている。そして，その具体的手段である農村整 借事莱が, 特に重要視されているのである。

\section{4 树鳌错事菜の方针}

政府は第 5 次マレーシアブランの中で, 集団経 営 (Group farming)による農業の振興と，冁村都 市化 (Rural urbanization) による教育・保健・厚 化・水道事莱など, 広い分野にわたる公共サービ スの充実と屋用の開発により，農村の住民の経済 と福祉を增進し，都市との経済格差を正す事を， 農村整借の目標に揭げている。農村の貣困性につ いては，小規模経営・収益性の低い作物の栽培・ 生産方式の後進性・経営資金の弱体・実効の上が らない㡾業振興対策・唇菜従事者の老跲化・労力 不足・小作地の非効率的土地利用などがその要因 であると分析している。

展村都市化では，1984年に開始された農村セン ター (Rural growth centre) 整甭事業を, 積極的に 押し進める事を䛠っている。農村センターという のは，㕕域に散在している幾つかの集落を統合 し，ここに地域の経済・公共サービスなどの機能 を効染よく集中し，これを地域晨業に関連する軽 工業や，経斉活動の核に育て上げようとするもの である。これにより，地方産業の振興を図り，国
表 1 マレーシアにおける産業別就業労力 $(1985 \text { 年 })^{11}$

(坚位：千人)

\begin{tabular}{|c|c|c|c|c|}
\hline 産羍部門 & マレー人 & 中国人 & その他 & 計 \\
\hline 婁 漁業 & 1,429 & 318 & 206 & 1,953 \\
\hline 工钩業 & 522 & 633 & 113 & 1,268 \\
\hline 商業部門 & 362 & 512 & 71 & 945 \\
\hline 公䅦員 & 506 & 222 & 92 & 820 \\
\hline 一その他 & 283 & 142 & 58 & 483 \\
\hline 郡 & 2,031 & 1,827 & 540 & 5,469 \\
\hline 失蓝者数 & 296 & 105 & 48 & 449 \\
\hline
\end{tabular}

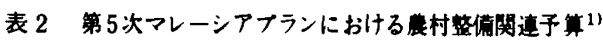

(临位：百万マレーシフトル)

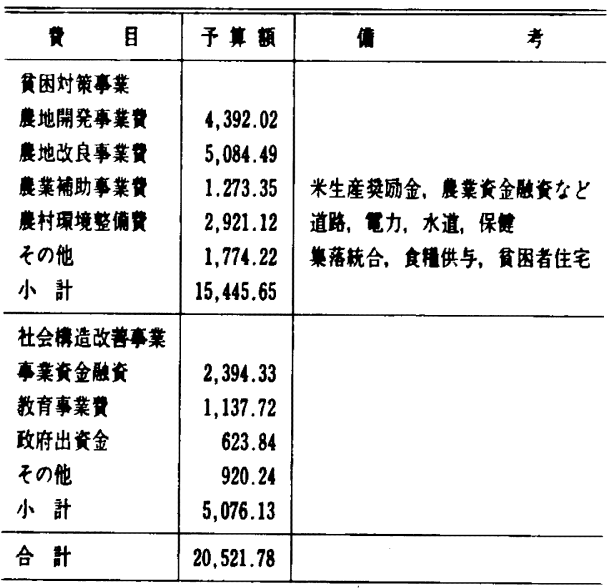

内需要を掘り起こし，新しい㢆用を創造し，辰村 地带の負困世帯の救済とともに，地方から大都市 への人口流出が抑えられる事を期待している。

簕者の手許には㗄料がないため,この事業の具 体的な実例を、ここに述べられないのは, 誠に残 念である。

\section{5 濐村整備関連予算}

連邦政府と公団 (FELDA - RISDA - FELCRA な ど）を合わせた，第 5 次マレーシアプラン 5 カ年 間の予算は，M\$741億である。うち，農業・辰 村開発事業費は， $M \$ 87$ 億である。これは，商 工業のM\$202億, 交通の M\$130億に次ぐ予算皟 
である。

農業・農村開発事業費に，他部門に計上されて いる農村整備関連予算を加えると，全予算の $29 \%$ を占めるＭ\$205億になる (表 2 参照)。このう

ち, 農用地開発と雾紐農民の入植を図る農地開発 事業費と, 灌溉排水・コム改植・荒廃地のリハビ リテーションなど, 既耕地を对象とした晨地改良 事業費 (In situ development) が，予算のほほ半分 を占める。その他，生産奖励金・肥料無供供与 ·

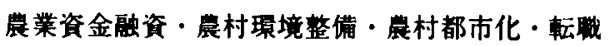
資金融资・職業訓練などの予算が計上されてい る。

\section{II ム夕地区の農村の実態と問題点}

\section{1 ムダ地区の桯要}

マレーシア・ム夕地区は，半島マレーシア，西 海岸, 最北部に位置する $96,000 \mathrm{ha}$ の水田地带で ある。ム夕地区は、「マレーシアの米倉」と言わ れ, 商品生産的性格の強い稲作経営が行なわれて いる。鹿家戸数は現在約 6.3 万戸，農家人口は 36 万人である。百年ほど前から，貴族支配階層によ る開田事業が盛んに行われ出し，水田面積を大幅 に拡大した。1966年から1970年にかけての第 1 次 マレーシアプランにおいて，国民の主食であるコ メの自給率と，農民の生活水望の向上を目的とし て, 基幹的水利施設が整備され，水稲二期作の亚 入に成功している。更に，第 3 次マレーシアブラ

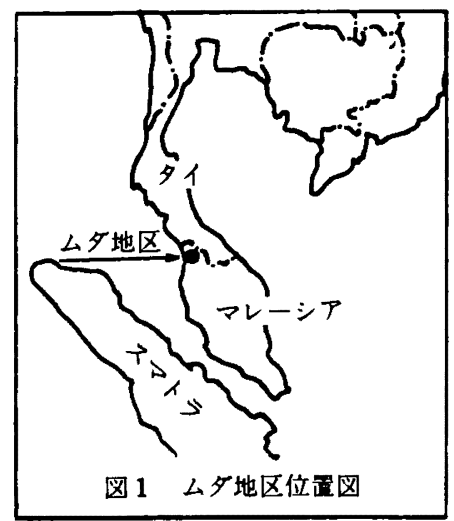

ンにおいては, 15力年計画の末端水利施設の整㣁 事業 (Tertiary development) に着工し, 現在工事 が進んでいるところである。

\section{2 榴作経営の実態}

ム夕地区の平均経営面皘は約1.6ha で，国内で は最も释営规模の大きな地区である。経営規模別 農家戸数分布を見ると， 1 ha 前後の農家が多く， 1.7 ha 以下の宸家で 3 分の 2 を占めている（表 3)。一方, M A D A (ム夕農業開発公団：Muda Agriculture Development Authority)の発表による と，1983年時点のム夕地区内の貧困世带の率は， $46 \%$ にも上る。そのうち，M\$40/月/人以下 の収入しかない, hard-core poor と呼ばれる極隻 世帯は，実に32\%にも達する。ム夕地区でも，需 細な経営规模と貧困が，大きな問題となっている ことがわかる。

1981年第 1 作（オフシーズン）に，180戸の農

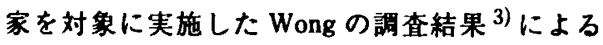
と，么夕地区の稲作経営の収支は，表 4 のように なる。1.2 ha 以下の農家事 $42 \%$ は，上記の筫困 世帯率46\%にほほ一致する。180戸の平均経営面 積は1.39 ha であるが，これは筫困ラインすれす れの规模といえる。収入のほとんどは，収權モミ の売却によるものである。零細農家が多い割に は，労货収入が極めて少ない。補助金というの は, 稲作尨家の所得水华を改善するため, $60 \mathrm{~kg}$ 当 たり標华MS 28 （モミ）の生産者価格に上乗せし た，M\$10のことで，展業所得の37\%にもなる。 全国平均では，純宸業所得M\$1，780/戸のうち， 補助金は67\%のM\$1，230（1984年）にもなる。 これも，富める中国人から吸い上げた税金を，頜

表 3 経嘗规模別農家戸数分布 ${ }^{51}$

\begin{tabular}{l|c}
\hline \hline \multicolumn{1}{|c|}{ 経営規模 } & 分布 $(\%)$ \\
\hline $0.6 \mathrm{ha}$ 以下 & 10 \\
$0.6 \sim 1.2 \mathrm{ha}$ & 32 \\
$1.2 \sim 1.7 \mathrm{ha}$ & 25 \\
$1.7 \sim 2.3 \mathrm{ha}$ & 12 \\
$2.3 \sim 2.9 \mathrm{ha}$ & 9 \\
$2.9 \sim 3.5 \mathrm{ha}$ & 7 \\
$3.5 \mathrm{ha}$ 以上 & 5 \\
\hline
\end{tabular}


しい稲作宸民に透元するための，マレー優遇政策 の一䍗である。

支出では，収權费が最大の带目となっている。 これと耕うん整地表は，宸作業請負業者に支払わ れる。ム夕地区では，二期作化事業に伴い，収穫 ・耕うんははは100\%機械化されている。機械の 所有者の多くは, 町の人間, すなわち華僑であ る。機械を所有し，作業を請け負っている大規模 宸家もあるが，その数はわずかである。表 3 の収 入の項にある耕請負費がそれにあたり, 支出の耕 うん整地費の13\%になっている。結局，残り87\% は町の人間に流れていることになる。この表で見 る限りは, 収穫費のほとんどは, 町の人間に持っ ていかれていることになる。

従来，収權作業は，労俰で生計を立てていた零 勫農家の，貴重な収入源であった。農作業の機械 化は，需細展民の収入源を靠ったが, 大規模農家 には, 生産コスト低娍の恩恵を, 町の人間には, 絶好のヒジネスの機会を与えた。

表 4 厶夕地区における稲作経営の鹿業所得3)

\begin{tabular}{|c|c|}
\hline : & $M \$$ \\
\hline \multicolumn{2}{|l|}{ 支出 } \\
\hline 同料 & 12.85 \\
\hline 慰来 & 4.69 \\
\hline その他敨材 & 13.68 \\
\hline 耕うん整地 & 157.98 \\
\hline 移植 & 169.85 \\
\hline 収秘 & 330.30 \\
\hline 属用労俱 & 21.19 \\
\hline 通法费 & 99.26 \\
\hline 借地料 & 295.47 \\
\hline 税金 & 194.96 \\
\hline その他 & 2.70 \\
\hline 計 & $1,302.93$ \\
\hline \multicolumn{2}{|l|}{ 收入 } \\
\hline モミ販売額 & $2,330.01$ \\
\hline 労共収入 & 26.51 \\
\hline 耕うん碃負 & 20.00 \\
\hline その他 & 7.38 \\
\hline 補助金 & 634.59 \\
\hline 計 & $3,018.49$ \\
\hline 婁業所得 & $1,715.56$ \\
\hline
\end{tabular}

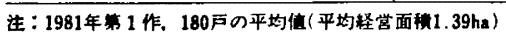

\section{3 费村の実態}

集落は, 散居ないし集居形式で，二期作化事業 以前、まだ道路網が整備されていなかった時代 に，舟運用運河として利用されていた水路に沿っ て，列状に発達した集落が比較的多く見られる。 熱帯農業研究センターの研究対象地区内の集落の 状況は，図2のようである。

いろいろなケースがあると思われるが，熱带農 業研究センターの研究対象地区の場合には，稲作 宸民の住宅は，必ずしも，所有田と同じ集落内に あるとは限らない。面程 760 ha の潅溉フロック における山下の調查 ${ }^{2)}$ によると, フロック内の水 田を耕作している416戸の農家の内, フロック内， ならびにフロックに陊接する 6 集落に住んでいる 農家は103戸に過ぎず, 他の313戸はプロック外の 104集落に住んでいた。

このような，土地と住民とが一致しない集落形 態は，電話も全く普及していない農村地带にあっ ては，水田基盤整備事業推進のうえで，大きな障 害となる。現在, マレーシア政府が実施中の末端 娄場施設整備事業では，農民による造成施設の維 持管理を計画しているが，同じ地域の水田を耕作 していながら，異なる集落に分散して住んでいる 農民をまとめて, 水利組合を組織し, 運営してゆ く事は，極めて困難である。このため，施設工事 完了後も, 維持管理が適正に行われず, 事業効果 の発現に，大きな障害となっている。

\section{4 患民と生活の実態}

ム夕地区の農民の家族数は多く，平均5.4人で， 10人以上の子供がある世帯もまれではない。半島 マレーシア全体の人口增加率は, 年 $2.5 \%$ である が，中国人の $1.7 \%$ に対して，マレー人の $2.9 \%$ という，際立って高い事がこれを亳付けている。 衛生および栄養面での問題があり，1980年には， ムタ地区を含むケダ州全体で1,000人当たり28.7 人もの乳児死亡事を記録している。その後，食糧 支給事業による栄養改善, 保健所增設などの努力 が実り，1984年には21.0人まで低下させる事に成 功している。

衛生面では，特に水に問題がある。厚い粘土層 


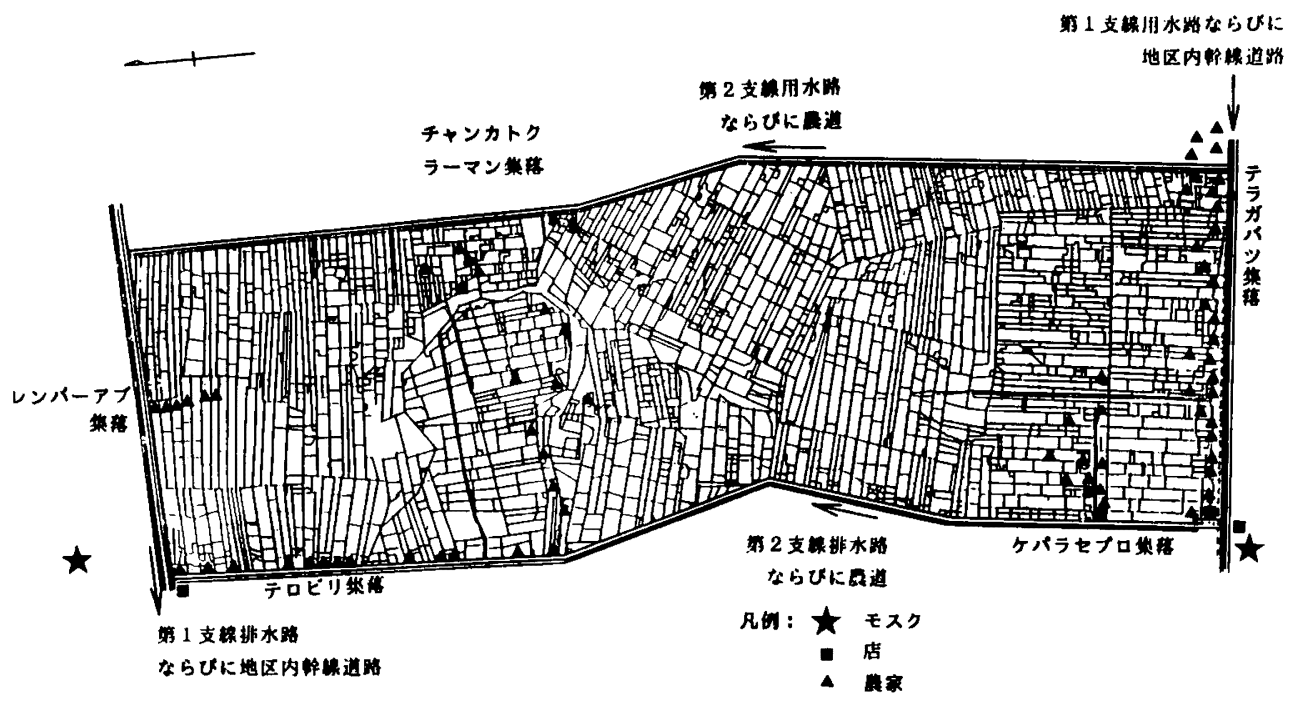

図 2 厶タ地区における集落配宜の状況（ACRBD 4 潅溉フロック、1986年）

で形成されているム夕平原では, 地下水が利用出 来ないため, 飲用水には雨水, 沐浴や洗い物には 水路の水を用いている。集落排水施設が整備され ておらず，生活排水をタレ流しにしているムタ地 区では、このため, 毎年, 水路の流量が減少する 乾季になると，水質が著しく悪化し，コレラなど の伝染病が度々発生する。交通の便のよい集落で は, 給水車による給水が受けられるが, 辺郎な集 落では，水路の水を漉して利用したり，遠方まで 水を汲みにゆかざるを得ない。農村部への水道管 の布設も徐々に行なわれて居り, 主要道路治いの 莀家は，水道水の供給を受けられるようになって きているが，水道管の引き込みには1戸当たり $\mathrm{M}$ $\$ 450$ もかかるので, 零細辰家にとっては, 高嶺 の花である。水道を引けない農家は，18リットル 当り $M \& 1$ で, 水道を引いた農家から買水して いる。

栄面では，米飯にカレーをかけただけとい う, 简単な食事が多く, 特に動物性蛋白質が不足 している。料理には，コレステロールの含有車が 極めて高いヤシ油や，砂糖を好んで多用し，栄養 のバランスも取れていない。水路や水田で取れる
魚やエビは，農民の共重な蛋白源であるが，農薬 使用量の增加に伴う污染が，㫘虑されている。

マレーシア政府は, 中学校までの授業料を無償 にしたり，学校を増やすなどして，教育にはこと に力を入れている。ムタ地区内をドライフしてみ ても，造られたばかりの真新しい学校が，水田の 中にポッンと立っているのがよく目につく。全国 レベルの就学本は小学校が $99.0 \%$, 中学校が87.3 \%と, 閐発途上国の中にあっては, 著しく高い。

\section{III ム少地区における農村整備の方向}

第 5 次マレーシアプランの中では，ムタ地区は， 水稲生産の重点地区として位置付けられている が, その具体的施策の内容は，明らかではない。 稲作振興策として，集団化と企業化 (Padi estate) による大規模経営を上げているだけで，具体性に 欠けている。

ここで，ムタ地区を対象にして，展村整備に関 する䈉者の個人的な意見を述べることにする。ご く常識的な方策ではあるが，ムダ地区の榴作の振 
興を図るには，経営面積の拡張，生産量の增加， 生産コストの低娍を実現してゆくしかないであろ う。しかし，それには多くの制約因子が絡み，農 村整储と人造りを軸とした，総合的な取り組み態 势が求められる。

\section{1 稻作振興の意味}

マレーシアの第二次，三次産業が大いに振興 し，大量の労儌者を求めているのであればいざ知 らず，経済が低迷し，労倠人口の自然增の吸収さ えもままならない現状では，多くの弱小晨民を切 り捨て，小数の優良展民を育てるような稻作掁興 策は，社会不安を助長させるだけである。むし ろ，農村地域内での利益配分の平等化を図り，落 伍者をできるだけ出さない事が，マレー優遇政策 の趣旨にも沿い，現在のマレーシアにおける今日 的稲作振興策と思われる。

\section{2 経営規模の㹡張}

ムタ地区には，もはや新たに開田する余地は無 いので, 程営面積の抎張は，展民の数を減らす事 を意味する。晨民の数を減らすには，それに見合 う新たな雇用を隼借しなければならない。経営奻 事の悪い零細農民の鹳農を促進することになる が，5力年計画の中でさえ，将来の失業率增加を 見込んでいる位であるから（前述），その再就職 は容易ではない。埨出か不振で, 释済不況に陥っ ているマレーシアの現状では，零細農家の無思虑 な雒農促進策は，都市のスラムを膨張させ，社会 不安を高めることになる。

都市部では既に，国有地なとにに Twenty hours building と呼ばれるバラックを無断で建て，住み 着いてしまうスクォーターの対策に，手を焼いて

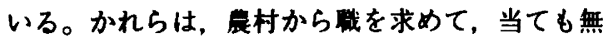
く都会にでてきた筫しい宸民達と思われるが，そ の数は20万人以上に達するといわれている。その ほとんどは，定聝を持たず，建設現場の日雇労働 者などの安易な珴に就き，生計を立てている。ま た，犯罪者源となって，大きな社会問題となって いる。

都市で安定した職に就けるのは，十分な教育・ 訓練を受け，知識や技術を身に着けた若者達であ
ろう。蓶農した宸民の生計確保の確証無しに, 経 営规模拡大策を採ることには，大きな問題が残 る。

\section{3 生産悬の增加}

生産量の增加は, 作付率と収量の增加により達 成出来る。ム夕地区では, 約 $75 \%$ の二期作化率 と、 $4 \mathrm{t} / \mathrm{ha}$ の収量に達している。はるかに品 質のよい夕イ米の輸出価格3.7万円／ $\mathrm{t}^{4)}$ と比較 して, 前述の補助金も含めると, 精米（モミから

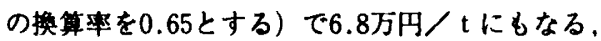
著しく高い生産者米価が示すように, マレーシア の稲作は，国際媇争力に欠けているといえる。こ のため，生産過剩を恐れるマレーシア政府は、コ メの自粭事達成目標を，80\%に設定している。19 85年時点の国内需要は2.5百万 $\mathrm{t}$ （モミ）で，従 って, 生産目標䫫は 2 百万 $\mathrm{t}$ になるが, 生産高は 既に1.93百万 $\mathrm{t} に$ 達しており, 最近政府は, コメ の生産抑制策をほのめかし始めている。大幅な生 産量增加による経営改善にも, 先行きに, 楽钼が 許せない情勢になってきている。今後は，年2.5 \%の人口增加率に見合うだけの生産量增加を，徐 々に図ってゆけばよいのである。

\section{4 生産コストの低減}

宸作業の機械化が進んでいるム夕地区の稲作労 働時間は, 1 ha 当たり, 人力移植栽培で255時 間，直播栽培で140時間であり $\eta^{3)}$ ，日本の 3 分の 1 ないし 4 分の 1 にしか過ぎない。また，层業資 材费も著しく低く（表 4 参照）, 極めて省力的, 省資源的栽培が行なわれている。

ム夕地区の稆作の支出（表 4) を見ると、耕う ん・整地・収模の機械化農作業請負業者への支 払, 借地料, 税金, ならびに, 移植の労務费など の支出が主なものである。生産コストの低娍は, これらの支出を節減する事を意味する。農作業の 機械化は, 人力作業よりも経済的であるという理 由で普及したもので, この分野における経節隇 は, あまり期待出来ない。借地料 - 税金は, 释営 努力や技術革新では对処出来ず，政治的な社会 · 法律制度の見直しを待つしかない。移植労務費 は, 直播栽培の導入により大幅に節隇出来るが, 
末端戋場施設が整備されておらず，圈場水管理が 困難な現状ではリスクが大きい。

こうして見ると，生産コストの低減も，現在進 められている末端基盤整備が完成し，水管理が合 理化されてからということになる。

\section{5 量村地域内での利益再卧分}

二期作咅入後，ム多地区の中心部にあるコメの 集散地で, ケダ州の首都でもあるアロースターの 町の発展ぶりには，目を見張るものがある。農村 部でも，立派な家を建てたり，乗用車を睛入する 宸家が，少なからず見られた。二期作化事莱が, 地域経済に大きなインバクトをもたらした事は, 紛れもない事実である。

先ず, 二期作化事莱に伴う水利施設や道路の建 設工事で，建設業者が大いに洞った。次に，二期 作学入に伴うコメの增産で, コメの流通を扱う商 人が湖った。勿論，大規模農家にとっては，增産 の経済的メリットは大きい。さらに、これによる 地域全体の瞔買力向上により，一般商人も潤う。 また，機械化農作業請負業の普及に伴い，高価な 機械を睛入出来乃商人や，大規模農家が閏った。 一方，零細農家は，真労扸の機会を失い，高滕す る借地料により，むしろ，分困の度合を增してい った。

先進国の人間から見れば,これは，農業近代化 の過程における，必然の現象に過ぎない。しかし， 「筫因からの脱出」を大蒋名分に，二期作化事莱 を実施したマレーシア政府にとっては，極めて咨 虑すべき問題である。開発途上国独特の課題とし て，事業効果の公平な再配分の途を，今後研究し てゆく必要がある。

\section{6 ムダ地区における脚柾の方向}

これまでに述べてきた，ムタ地区を取り巻く諸 情慜に篮み，ム多地区における農村整備では，現 在の地域住民が公平に利益の配分を受けられる様 な，生産および社会組織を策く事が，大きな課題 となろう。それには，人造りを通して，地域内の 雇用を開発し，人の再配置を促す事が重要であ る。

一例として，大部分が展業部門外に流出してし
まっている，機械化農作業請負料金の地区内嗃流 を図る事が, 有力な手段として考えられる。地区 内には，職業訓練学校、慰業機械化訓練センター などが完借しており、これらを利用して技術移転 を推進し，第 5 次マレーシアプランにも計上され ている事業資金融資（表 2 参照）により，垄民に よる機械化展作業請負業を育成する。

これからも，長期間にわたり継続する末端國場 施設整借 - 集落統合事業・辳村環境整備事業など に伴う建設工事についても，同じ事が言える。建 筑, 土工, コンクリート二次製品製造, 重機械才 ペレーションなどの技術を展民に移転し，简単な 工事を請け負わせ、これまで部外に流出していた 工事费の，地区内运流を図るとともに，技術を更 に研錪させ，行く行くは建設業者として自立でき るようにする。

機械工やかじ工が育てば，简単な農業機械（夕 イ農村でよく見掛ける，廃物を利用して作った宸 民車・トレラー・ボリュートボンプなど）や宸機 具の製造や修理も可能となり，将来の慰村工業発 達の原助力となろう。甚だ月並ではあるが，何れ にしろ，鹿村振興のためには，人造りを軸にした 農村整備事業の推進が不可欠であるというのが, 筆者の㰴論である。

おわりに

ムタ地区だけでも，毎年䄪 1 万人の展村人口の 自然增がある。上述のような方法で、これだけの 㕍用を地区内に作り続けてゆく事は，不可能と言 ってもよいであろう。人口数のうえで, マレー人 の圧倒的優位を保たねばならぬ，椱合民族国家ゆ えの特殊事情から，産坚制限政策も取れないマレ ーシア政府の苦惔を思い, 深い同情の念を禁じ得 ない。

最後に，本稿執筆にあたり，マレーシアで凘料 収集の労をとって頂いた, 熱带農業研究センター の南部博氏に，心からの感謝を表します。 


\section{引用文苚}

1) マレーシア政府：Fifth Malaysia Plan 19861990. p. 1-549. 1986

2) M. Yamashita : Farm management study, pilot project ACRBD4 Muda Irrigation scheme. Tech. Bull. Trop. Agr. Res. Center. p. 1-77. 1981.

3) Wong H. S. : Muda II evaluation study preproject status--The farm household economyoff season 1981. p. 1-43. 1983.

4) FAO : Monthly bulletine of statistics. Vol. 9. p. 59. 1986.

5) MADA : Feasibility report on tertiary irrigation facilities for intensive agricultural development in the Muda irrigation scheme Malaysia. Annex 3. Fig. 1. 1977. 


\section{Rural Development in Indonesia \\ Hiroyuki NisHimuRA \\ (Faculty of Agriculture, Kyoto University)}

Regional agricultural development planning or integrated development planning in Indonesia was in operation until the 1960s. Since the 1970s agricultural or rural development has aimed mainly to correct imbalances among the regions and to pursue social equality among the different classes of the people. These policies were not only looking for economic growth but also making efforts towards eradication of poverty.

The recent 4th five-year development plan has been in operation since 1984. The main objectives of the rural development in this plan are set on (1) agricultural production which copes with the needs of the people, (2) development of cooperative activities, (3) creating job opportunities in the rural areas, (4) support to the poor, and (5) promotion of family planning.

According to the Ministry of Interior, The Government of Indonesia, the share of "Swasembada (well-developed and viable villages)" in the total number of villages was 22 percent in 1983 . The Government expects it to reach hundred percent by the year 2000 .

"Program Kabutaten" (Prefectural Program), "Padat Karya" (Labor Intensive Work), and "Program Subsidi Desa" (Village Subsidy Program) are other kinds of village development programs which aim to expand job opportunities and improve the infrastructure in the rural areas.

As a particular type of rural development, transmigration programs have been conducted in order to decrease the population pressure in the densely populated areas like Java and to give working opportunities to transmigrants in the outer islands. Agriculture is lain as the central concern of the transmigration programs.

The main tasks in the present rural development are (1) identification of target groups and effective assistance to them in the developing processes, (2) reformation in organizations and management of the development programs, (3) better land use planning, (4) improvement of transmigration program, and (5) securing people's active participation in the development programs.

\section{Rural Planning in Malaysia}

by Shigeo YASHIMA

(Tropical Agriculture Research Center)

Rural development is an important policy in the Fifth Malaysian Plan (1986-1990) as an efficient countermeasure for 1) large gaps in living standards between urban and rural areas, 2) concentration of population in urban areas, 3) increasing unemployment and 4) stagnant industrial development.

The Malaysia Government expects that urbanization of rural areas will alleviate those problems leading to 1) promotion of rural industry, 2) creation of employment opportunities, 3) enhancement of incomes, 4) provision of public services and 5) increased living standard for rural inhabitants.

In the Muda area, which is a representative paddy production area of the country and $46 \%$ of whose paddy farmers are under the poverty line, an increase in paddy production may not be a solution to the problems as the national target of rice self-sufficiency has been attained. Its development needs shoring up by the development of human resources along with local industries. 